\title{
Predictors for High Microsatellite Instability in Patients with Colorectal Cancer Fulfilling the Revised Bethesda Guidelines
}

\author{
KEIICHI ARAKAWA, KEISUKE HATA, KAZUSHIGE KAWAI, TOSHIAKI TANAKA, \\ TAKESHI NISHIKAWA, KAZUHITO SASAKI, YASUTAKA SHUNO, MANABU KANEKO, \\ MASAYA HIYOSHI, SHIGENOBU EMOTO, KOJI MURONO and HIROAKI NOZAWA \\ Department of Surgical Oncology, the University of Tokyo, Tokyo, Japan
}

\begin{abstract}
Background: The revised Bethesda guidelines $(r B G)$ are generally used for screening of Lynch syndrome, and few researchers have investigated the associations between microsatellite instability (MSI) status and each item of the rBG. Patients and Methods: This retrospective study included patients with colorectal cancer who were classified into those fulfilling the $r B G$ (Bethesda group) and those not (control group). The breakdown of each item in the $r B G$ and predictors of high MSI (MSI-H) were determined in the Bethesda group. Results: Of 809 consecutive patients, 161 (19.9\%) were found to fulfil the $r B G$ criteria. As a predictor of MSI-H, items 2 or 5 of the $r B G$ showed a sensitivity of 93.3\%. Item 5 and right-sided tumour location were independent predictors of MSI-H in patients fulfilling the $r B G$ (odds $\operatorname{ratio}(O R)=4.49$ and 25.1; $p=0.0260$ and $<0.0001$, respectively). Conclusion: Item 5 of the $r B G$ and right-sided tumour location are significant predictors of MSI-H.
\end{abstract}

Lynch syndrome (LS) is a common autosomal dominant disorder that accounts for approximately $1-3 \%$ cases of colorectal cancer (CRC) (1). In 1991, the Amsterdam criteria were originally designed to select families appropriate for enrolment in research projects aimed at identifying the genetic causes of hereditary CRC. In 1999, these criteria were extended to extra-colonic cancer associated with LS (2). However, even the revised Amsterdam II criteria have relatively low sensitivity for diagnosing $\operatorname{LS}(2,3)$. On the other hand, in 1997, the National Cancer Institute hosted an international workshop to develop criteria and identify

Correspondence to: Keiichi Arakawa, M.D., Department of Surgical Oncology, University of Tokyo Hospital, 7-3-1 Hongo, Bunkyo-ku, Tokyo 113-8655, Japan. Tel: +81 338155411 (ext. 37083), Fax: +81 338116822, e-mail: keiichiarakawa@hotmail.com

Key Words: Colorectal cancer, Bethesda guidelines, Lynch syndrome. patients with CRC who should be offered microsatellite instability (MSI) testing due to an increased risk for LS, and concurrently suggested the Bethesda guidelines with less stringent criteria than the Amsterdam criteria (4). These guidelines queried the patient's medical and familial history of LS-related tumours and early age of onset. In 2004, these guidelines were revised to achieve higher specificity (5).

Some studies recommended universal testing of MSI or immunostaining for mismatch repair proteins in all patients with newly diagnosed CRC. However, universal screening is not cost-effective in clinical practice (6). In general, the preselection of patients with LS based on clinical criteria seems to be a more cost-effective approach (7). At present, the Japanese guidelines for hereditary CRC recommend the use of the revised Bethesda guidelines ( $\mathrm{rBG}$ ) for the primary screening of LS (TabIe I), and patients who fulfil the rBG have been recommended for testing for MSI (8). The proportion of patients fulfilling the rBG was $16-47 \%$ in all types of CRC in previous studies $(6,9,10)$. Furthermore, in other studies, the proportion of patients with high MSI (MSI-H) was $12-18 \%$ in patients fulfilling the $\mathrm{rBG}$, and the proportion of those with LS was $2-4 \%$ in patients fulfilling the rBG (11-14). In this study, we aimed to assess the relationship between each item of the rBG and MSI-H status to seek a more cost-effective approach for selection of patients with MSI-H tumours. In particular, we identified the independent factors predictive of MSI-H among patients fulfilling the $\mathrm{rBG}$.

\section{Patients and Methods}

The medical records of patients with CRC who underwent surgical resection between January 2014 and December 2017 were retrospectively collected from the database of the Department of Surgical Oncology at the University of Tokyo, Japan. All surgically resected specimens were histopathologically reviewed. Tumour staging was determined according to the criteria of the Union for International Cancer Control (UICC) TNM classification (15). Patients were categorized into two groups: those fulfilling the $\mathrm{rBG}$ 
Table I. The number and proportion of cases fulfilling the revised Bethesda guidelines.*

\begin{tabular}{|c|c|c|}
\hline Item & Revised Bethesda Guidelines & $\begin{array}{c}\text { This study, } \\
\mathrm{N}(\%) \\
(\mathrm{N}=161)\end{array}$ \\
\hline 1 & Colorectal cancer diagnosed in a patient under 50 years of age. & $68(42.2)$ \\
\hline 2 & Presence of synchronous, metachronous colorectal, or other LS-associated tumours, regardless of age. & $65(40.4)$ \\
\hline 3 & Colorectal cancer with the MSI-H histology diagnosed in a patient under 60 years of age. & $3(1.9)$ \\
\hline 4 & $\begin{array}{l}\text { Colorectal cancer diagnosed in one or more first-degree relatives with an LS-related tumour, } \\
\text { with one being diagnosed under } 50 \text { years of age. }\end{array}$ & $6(3.7)$ \\
\hline 5 & Colorectal cancer diagnosed in two or more first-or second-degree relatives with LS-related tumours, regardless of age. & 47 (28.6) \\
\hline
\end{tabular}

LS, Lynch syndrome; MSI-H, high microsatellite instability. *Modified from (5).

(Bethesda group), and those not (control group) (Table I). Our focus was on the Bethesda group, and the proportion of patients fulfilling each criterion of the $\mathrm{rBG}$ in this group was evaluated. We also assessed the combination of each item for high sensitivity for prediction of MSI-H. MSI status was assessed using five microsatellite loci: BAT25, BAT26, MONO27, NR21, and NR24 for patients in the Bethesda group. The locations of tumours and MSI status in the Bethesda group were evaluated and stratified by the item number of the rBG. The sensitivity and specificity for prediction of MSI-H were calculated using numbers of patients fulfilling each rBG. Additionally, we assessed the number of patients required in order to identify one patient with MSI-H and the proportion of patients with MSI-H who would be missed for each item of the rBG. Moreover, independent factors predicting MSI-H were sought in the Bethesda group. Tumour location and MSI status were evaluated in association with each $\mathrm{rBG}$ item and their combination.

This study was approved by the Ethics Committees of the University of Tokyo [no. 3252-(6)]. The research was conducted according to the principles of the Declaration of Helsinki.

Statistical analyses. Differences in the categorical variables between the Bethesda and control groups were examined using the Chisquared or Fisher test, as appropriate. The independent predictive factors for MSI-H were also assessed using logistic regression analysis. Values of $p<0.05$ were considered statistically significant. All statistical analyses were conducted using JMP software version 10 (SAS Institute Inc., Cary, NC, USA).

\section{Results}

A total of 809 patients were included in this study: 161 (19.9\%) patients fulfilling the $\mathrm{rBG}$ comprised the Bethesda group and $648(80.1 \%)$ patients formed the control group. Clinicopathological characteristics of the Bethesda and control groups were compared (Tables I and II). The proportion of patients fulfilling items 1 to 5 of the $\mathrm{rBG}$ were $42.2 \%, 40.4 \%, 1.9 \%, 3.7 \%$, and $28.6 \%$, respectively. Patients in the Bethesda group were significantly younger than those in the control group since the $\mathrm{rBG}$ includes CRC diagnosis in patients younger than 50 years. Tumour location by each rBG item and combinations of rBG are presented in Table III and MSI status in Table IV.
Table II. Clinicopathological features of all cases of colorectal cancer included in this study.

\begin{tabular}{|c|c|c|c|}
\hline & $\begin{array}{l}\text { Bethesda } \\
\text { group } \\
\mathrm{N}=161 \\
(19.9 \%)\end{array}$ & $\begin{array}{c}\begin{array}{c}\text { Control } \\
\text { group }\end{array} \\
\mathrm{N}=648 \\
(80.1 \%)\end{array}$ & $p$-Value \\
\hline \multicolumn{4}{|l|}{ Age (years) } \\
\hline Median (range) & $59(30-88)$ & $67(5-94)$ & $<0.0001^{*}$ \\
\hline \multicolumn{4}{|l|}{ Gender, $N(\%)$} \\
\hline Male & $98(60.9)$ & $372(57.4)$ & 0.4220 \\
\hline Female & $63(39.1)$ & $276(42.6)$ & \\
\hline \multicolumn{4}{|l|}{ CEA level (ng/ml) } \\
\hline Median (range) & $3.9(0.8-331)$ & $4.4(0.3-4256)$ & 0.2141 \\
\hline \multicolumn{4}{|l|}{ Location, N (\%) } \\
\hline Right & $38(23.6)$ & $193(29.8)$ & 0.1270 \\
\hline Left & $123(76.4)$ & $455(70.2)$ & \\
\hline \multicolumn{4}{|c|}{ Histopathology, N (\%) } \\
\hline WelI/mod & $147(91.3)$ & $605(93.4)$ & 0.3715 \\
\hline Other & $14(8.7)$ & $43(6.6)$ & \\
\hline \multicolumn{4}{|l|}{ T-Stage, N (\%) } \\
\hline 1 & $40(24.8)$ & $119(18.4)$ & 0.1527 \\
\hline 2 & $30(18.6)$ & $142(21.9)$ & \\
\hline 3 & $49(30.4)$ & $238(36.7)$ & \\
\hline 4 & $42(26.1)$ & $149(23.0)$ & \\
\hline \multicolumn{4}{|c|}{ LN metastasis, $\mathrm{N}(\%)$} \\
\hline Absent & $89(55.3)$ & $385(59.0)$ & 0.3874 \\
\hline Present & $72(44.7)$ & $265(41.0)$ & \\
\hline \multicolumn{4}{|c|}{$\begin{array}{l}\text { Lymphatic invasion, } \\
\mathrm{N}(\%)\end{array}$} \\
\hline Absent & $108(67.1)$ & $465(71.8)$ & 0.2466 \\
\hline Present & $53(32.9)$ & $183(28.2)$ & \\
\hline \multicolumn{4}{|c|}{ Venous invasion, $\mathrm{N}(\%)$} \\
\hline Absent & $76(47.2)$ & $265(40.9)$ & 0.1481 \\
\hline Present & $85(52.8)$ & $383(59.1)$ & \\
\hline \multicolumn{4}{|l|}{ Stage } \\
\hline $\mathrm{I}$ & $45(28.0)$ & $186(28.7)$ & 0.2796 \\
\hline II & $41(25.5)$ & $155(23.9)$ & \\
\hline III & $58(36.0)$ & $203(31.3)$ & \\
\hline IV & $17(10.6)$ & $104(16.1)$ & \\
\hline
\end{tabular}

CEA, Carcinoembryonic antigen; LN metastasis, lymph node metastasis; Muc, mucinous carcinoma; Mod, moderately differentiated adenocarcinoma; Wel, well differentiated adenocarcinoma. *Significance accepted at $p<0.05$. 
Table III. Relationship between tumour location and each item of the revised Bethesda guidelines in the Bethesda group.

\begin{tabular}{|c|c|c|c|c|c|}
\hline \multicolumn{2}{|c|}{ Revised Bethesda Guidelines } & \multirow{2}{*}{$\begin{array}{l}\text { Overall } \\
\mathrm{N}=161\end{array}$} & \multirow{2}{*}{$\begin{array}{c}\text { Right } \\
38(23.6 \%)\end{array}$} & \multicolumn{2}{|l|}{ Left } \\
\hline Item & Response & & & $121(66.4 \%)$ & $p$-Value \\
\hline \multirow[t]{2}{*}{1} & Yes & $68(42.2 \%)$ & $6(8.8 \%)$ & $62(91.2 \%)$ & $<0.0001^{*}$ \\
\hline & No & $93(57.8 \%)$ & $32(34.4 \%)$ & $61(65.6 \%)$ & \\
\hline \multirow[t]{2}{*}{2} & Yes & $65(40.4 \%)$ & $18(27.7 \%)$ & $47(72.3 \%)$ & 0.3170 \\
\hline & No & $96(59.6 \%)$ & $20(20.8 \%)$ & $76(79.2 \%)$ & \\
\hline \multirow[t]{2}{*}{3} & Yes & $3(1.9 \%)$ & $1(33.3 \%)$ & $3(66.7 \%)$ & 0.7000 \\
\hline & No & $158(98.1 \%)$ & $37(23.4 \%)$ & $121(76.6 \%)$ & \\
\hline \multirow[t]{2}{*}{4} & Yes & $6(3.7 \%)$ & $3(50.0 \%)$ & $3(50.0 \%)$ & 0.1521 \\
\hline & No & $155(96.3 \%)$ & $35(22.6 \%)$ & $120(77.4 \%)$ & \\
\hline \multirow[t]{2}{*}{5} & Yes & $47(28.6 \%)$ & $17(36.1 \%)$ & $30(63.9 \%)$ & $0.0187 *$ \\
\hline & No & $114(71.4 \%)$ & $21(18.4 \%)$ & $93(81.6 \%)$ & \\
\hline \multirow[t]{2}{*}{1 or 2} & Yes & $129(80.1 \%)$ & $24(18.6 \%)$ & $105(81.4 \%)$ & $0.0043 *$ \\
\hline & No & $32(19.9 \%)$ & $14(43.8 \%)$ & $18(56.3 \%)$ & \\
\hline \multirow[t]{2}{*}{1 or 5} & Yes & $101(62.7 \%)$ & $21(20.8 \%)$ & $80(79.2 \%)$ & 0.2795 \\
\hline & No & $60(37.3 \%)$ & $17(28.3 \%)$ & $43(71.7 \%)$ & \\
\hline \multirow[t]{2}{*}{2 or 5} & Yes & $109(67.1 \%)$ & $34(31.2 \%)$ & $75(68.8 \%)$ & $0.0007 *$ \\
\hline & No & $52(32.9 \%)$ & $4(7.7 \%)$ & $48(92.3 \%)$ & \\
\hline
\end{tabular}

*Significance accepted at $p<0.05$.

Table IV. Relationship between the microsatellite instability status and each item of the revised Bethesda guidelines in the Bethesda group.

\begin{tabular}{|c|c|c|c|c|c|c|c|c|c|}
\hline Revised & thesda Guide & ines Total & MSS & MSI-H & $p$-Value & Sensitivity & Specificity & NPR & $\begin{array}{c}\text { Patients with } \\
\text { MSI-H missed, } \\
\text { N (\%) }\end{array}$ \\
\hline Item & Response & $\mathrm{N}=161$ & $146(90.7 \%)$ & $15(9.3 \%)$ & & NA & NA & 10.7 & NA \\
\hline \multirow[t]{2}{*}{1} & Yes & $68(42.2 \%)$ & $63(92.7 \%)$ & $5(7.3 \%)$ & 0.4585 & 33.3 & 56.8 & 13.6 & $10(66.7 \%)$ \\
\hline & No & $93(57.8 \%)$ & $83(89.3 \%)$ & $10(10.7 \%)$ & & & & & \\
\hline \multirow[t]{2}{*}{2} & Yes & $65(40.4 \%)$ & $59(90.8 \%)$ & $6(9.2 \%)$ & 0.9753 & 40 & 59.6 & 10.8 & $9(60 \%)$ \\
\hline & No & $96(59.6 \%)$ & $87(90.6 \%)$ & $9(9.4 \%)$ & & & & & \\
\hline \multirow[t]{2}{*}{3} & Yes & $3(1.9 \%)$ & $3(100 \%)$ & $0(0 \%)$ & 0.4414 & 0 & 97.9 & - & $15(100 \%)$ \\
\hline & No & $158(98.1 \%)$ & $143(90.5 \%)$ & $15(9.5 \%)$ & & & & & \\
\hline \multirow[t]{2}{*}{4} & Yes & $6(3.7 \%)$ & $5(83.3 \%)$ & $1(16.7 \%)$ & 0.5639 & 6.7 & 96.6 & 6 & $14(93.3 \%)$ \\
\hline & No & $155(96.3 \%)$ & $141(91.0 \%)$ & $14(9.0 \%)$ & & & & & \\
\hline \multirow[t]{2}{*}{5} & Yes & $47(28.6 \%)$ & $38(80.9 \%)$ & $9(20.1 \%)$ & $0.0089 *$ & 60 & 74.0 & 5.2 & $6(40 \%)$ \\
\hline & No & $114(71.4 \%)$ & $108(94.8 \%)$ & $6(5.2 \%)$ & & & & & \\
\hline \multirow[t]{2}{*}{1 or 2} & Yes & $129(80.1 \%)$ & $119(92.3 \%)$ & $10(7.7 \%)$ & 0.1961 & 66.7 & 18.5 & 12.9 & $5(33.3 \%)$ \\
\hline & No & $32(19.9 \%)$ & $27(84.4 \%)$ & $5(15.6 \%)$ & & & & & \\
\hline \multirow[t]{2}{*}{1 or 5} & Yes & $101(62.7 \%)$ & $90(89.1 \%)$ & $11(10.9 \%)$ & 0.3620 & 73.3 & 38.4 & 9.2 & $4(26.7 \%)$ \\
\hline & No & $60(37.3 \%)$ & $56(93.3 \%)$ & $4(0.7 \%)$ & & & & & \\
\hline \multirow[t]{2}{*}{2 or 5} & Yes & $109(67.1 \%)$ & $95(87.1 \%)$ & $14(12.9 \%)$ & $0.0121 *$ & 93.3 & 34.9 & 7.8 & $1(6.7 \%)$ \\
\hline & No & $52(32.9 \%)$ & $51(98.1 \%)$ & $1(1.9 \%)$ & & & & & \\
\hline
\end{tabular}

MSS, Microsatellite stable; MSI-H, high microsatellite instability; NA, not applicable; NPR, number of patients required to identify one patient with MSI-H. *Significance accepted at $p<0.05$.

In this study, there were a few patients fulfilling items 3 $(1.9 \%)$ and $4(3.7 \%)$ of the rBG. In terms of tumour location, the proportion of patients with left-sided tumours was higher than that of those with right-sided tumours among patients fulfilling item 1 and items 1 or 2 . By contrast, the proportion with right-sided tumours was higher than that of left-sided tumours among those fulfilling item 5 and items 2 or 5 (Table III). 
Table V. Logistic regression analysis for predicting high microsatellite instability (MSI-H) for patients in the Bethesda group.

\begin{tabular}{|c|c|c|c|c|c|}
\hline \multirow[b]{2}{*}{ Factor } & \multirow[b]{2}{*}{ Subgroup } & \multirow{2}{*}{$\begin{array}{c}\text { Univariate analysis } \\
p \text {-Value }\end{array}$} & \multicolumn{3}{|c|}{ Multivariate analysis } \\
\hline & & & OR & $95 \% \mathrm{CI}$ & $p$-Value \\
\hline \multicolumn{6}{|l|}{ General variables } \\
\hline Gender & Male $v s$. female & 0.8185 & & & \\
\hline CEA (ng/ml) & $<5.0 \mathrm{vs} . \geq 5.0$ & 0.5275 & & & \\
\hline \multicolumn{6}{|c|}{ Cancer-related variables } \\
\hline Tumour location & Left $v s$. right & $<0.0001 *$ & 25.1 & $4.99-126$ & $<0.0001 *$ \\
\hline Pathology & Well/mod vs. poor/muc/sig & 0.0887 & 4.06 & $0.76-21.6$ & 0.0883 \\
\hline T Factor & $\mathrm{T} 1,2$ vs. T3,4 & 0.5472 & & & \\
\hline N Factor & N0 vs. N1 & 0.3749 & & & \\
\hline Lymphatic invasion & Absent $v s$. present & 0.4450 & & & \\
\hline Venous invasion & Absent $v s$. present & 0.8143 & & & \\
\hline M Factor & M0 vs. M1 & 0.1189 & & & \\
\hline \multicolumn{6}{|l|}{ rBG item } \\
\hline 1 & Yes $v s$. no & $0.0406^{*}$ & 2.83 & $0.60-13.3$ & 0.1886 \\
\hline 2 & Yes vs. no & 0.5873 & & & \\
\hline 3 & Yes $v s$. no & 0.4626 & & & \\
\hline 4 & Yes $v s$. no & 0.1215 & & & \\
\hline 5 & Yes $v s$. no & $0.0350 *$ & 4.49 & $1.20-16.8$ & $0.0260^{*}$ \\
\hline
\end{tabular}

CEA, Carcinoembryonic antigen; CI, confidence interval; MSI-H, microsatellite instability-high; Muc, mucinous carcinoma; sig, signet ring cell carcinoma; Mod, moderately differentiated adenocarcinoma; OR, odds ratio; rBG, Revised Bethesda Guidelines; Well, well-differentiated adenocarcinoma. *Significance accepted at $p<0.05$.

Table VI. The predictors for high microsatellite instability (MSI-H) for patients in the Bethesda group.

\begin{tabular}{|c|c|c|c|c|c|c|c|c|}
\hline & Total & MSS & MSI-H & $p$-Value & Sensitivity & Specificity & NPR & $\begin{array}{c}\text { Patients with } \\
\text { MSI-H missed, N (\%) }\end{array}$ \\
\hline All cases & $\mathrm{N}=161$ & $\mathrm{~N}=146$ & $\mathrm{~N}=15$ & & NA & NA & 10.7 & NA \\
\hline Right-sided tumour & $38(23.6 \%)$ & $26(68.4 \%)$ & $12(31.6 \%)$ & $<0.0001^{*}$ & 80.0 & 82.2 & 3.2 & $3(20.0 \%)$ \\
\hline Left-sided tumour & $123(76.4 \%)$ & $120(97.6 \%)$ & $3(2.4 \%)$ & & 20.0 & 17.8 & 41 & $12(80.0 \%)$ \\
\hline Patients fulfilling rBG items 2 or 5 & $\mathrm{~N}=109$ & $\mathrm{~N}=95$ & $\mathrm{~N}=14$ & & & & & \\
\hline Right-sided tumour & $34(31.2 \%)$ & $22(64.7 \%)$ & $12(35.3 \%)$ & $<0.0001 *$ & 85.7 & 76.8 & 2.8 & $2(14.3 \%)$ \\
\hline Left-sided tumour & $75(68.8 \%)$ & $73(97.3 \%)$ & $2(2.7 \%)$ & & 14.3 & 23.2 & 37.5 & $12(85.7 \%)$ \\
\hline
\end{tabular}

MSS, Microsatellite stable; MSI-H, high microsatellite instability; rBG, Revised Bethesda Guidelines; NPR, number of patients required to identify one patient with MSI-H. *Significance accepted at $p<0.05$.

The number of patients presenting with MSI-H was 15 $(9.3 \%)$ in the Bethesda group. The proportion of patients with MSI-H was higher among those fulfilling item 5 and those fulfilling items 2 or 5 (Table IV). Regarding the number of patients required to identify one patient with MSI-H, the combination of item 2 or 5 required eight patients, and missed only one patient among all 15 patients with MSI-H. In the logistic regression analysis, independent factors predictive of MSI-H included fulfilment of $\mathrm{rBG}$ item 5 and right-sided tumour (odds ratio=4.49 and 25.1, $p=0.0260$ and $<0.0001$, respectively) (Table V). In terms of correlation between MSI and tumour location, the number of right-sided tumours with MSI-H was higher than that of left-sided tumours with MSI$\mathrm{H}$. Additionally, with regard to fulfilling either $\mathrm{rBG}$ item 2 or 5, which had the highest sensitivity for prediction of MSI-H, details of which are presented in Table VI.

\section{Discussion}

In this study, we investigated each $\mathrm{rBG}$ item for association with MSI-H. The logistic regression analysis revealed that right-sided tumour and $\mathrm{rBG}$ item 5 were independent factors 
associated with MSI-H. The number of patients required to identify one patient with MSI-H was 11 in the Bethesda group, including three in the group with right-sided tumour and three among those fulfilling item 2 or 5 and with rightsided tumour location, which missed only $14.3 \%$ of the patients with MSI-H (Table VI). These results do not necessarily reflect the trends in the general population, since we did not conduct universal screening. Considering the cost-effectiveness of identifying patients with MSI-H, MSI testing may be better confined to patients with right-sided colonic tumour or those fulfilling $\mathrm{r}$ BG items 2 or 5 . This result suggests that care should be taken while collecting familial and past medical histories of patients regarding the presence of LS-associated tumours.

The findings of our study are consistent with those of a previous study reporting that tumours with MSI-H tended to be located in the right-sided colon (8). Our finding that familial history, as in item 5, was associated with MSI-H was likely due to selection bias because we included only patients fulfilling the rBG criteria. Two previous studies assessed each item of the rBG. Rodriguez et al. reported that item 1 of the $\mathrm{rBG}$ was independently associated with the presence of an MSH2/MLH1 germline mutation (16). Jung et al. reported that items 1 and 2 were independently associated with a deficient DNA mismatch repair gene (3). We did not investigate germline mutations, since the germline mutation test is not covered under medical insurance in Japan. However, mismatch repair gene mutations should ideally be investigated in patients with MSI-H.

Regarding tumour location by $\mathrm{rBG}$ item, tumours of patients fulfilling item 1 were more frequently located in the left side of the colorectum and those of patients fulfilling item 5 were more frequently located in the right side than those of patients not fulfilling it. Tumours of patients fulfilling either items 1 or 2 were located in the left side of the colorectum, and those of patients fulfilling either items 2 or 5 were located in the right side. These findings may be due to the relationships between items 1 or 5 and respective tumour locations.

This study had a few limitations. Firstly, we did not investigate germline mutations of mismatch repair genes in this study. There were two types of MSI-H-associated CRC: LS and sporadic; sporadic MSI-H-associated CRC is attributed to methylation of the $M L H 1$ gene. We were unable to differentiate these two types. Secondly, the cohort of this study included only patients surveyed with the $\mathrm{rBG}$, not all cases of CRC, since we focused on each item of the $\mathrm{rBG}$ among patients fulfilling the rBG. In a previous Japanese study, the proportion of patients with MSI-H ranged from $4.3 \%$ to $8.3 \%$ (17-19). Although identifying patients with MSI-H in the control group would have been ideal, analysis of those not fulfilling the rBG criteria was beyond the scope of this study. Thirdly, there were few patients who met criteria 3 or 4 of the $\mathrm{rBG}$. In some cases, eliciting the exact age of the family members at the time of cancer diagnosis was difficult, and due to the retrospective nature of this study, some pathologists might not pay attention to the MSI$\mathrm{H}$ histology, such as Crohn's-like reaction. This tendency was also reported in a previous study and may be a limitation of the rBG in clinical screening (3).

In conclusion, in patients with $\mathrm{CRC}$ who fulfil the $\mathrm{rBG}$, item 5 and right-sided tumours are factors predictive of MSI-H.

\section{Acknowledgements}

This research was supported by Grants-in-Aid for Scientific Research (C: grant number: 16K07143, C: grant number: 16K07161, C: grant number: 17K10620, C: grant number: 17K10621, C: grant number: 17K10623 and C: grant number: 18K07194) from Japan Society for the promotion of Science. This research is supported by the Project for Cancer Research and Therapeutic Evolution (PCREATE, grant number: $18 \mathrm{~cm} 0106502 \mathrm{~h} 0003$ from the Japan Agency for Medical Research and Development (AMED).

\section{References}

1 Hata K, Yamamoto Y, Kiyomatsu T, Tanaka T, Kazama S, Nozawa H, Kawai K, Tanaka J, Nishikawa T, Otani K, Yasuda K, Kishikawa J, Nagai Y, Anzai H, Shinagawa T, Arakawa K, Yamaguchi H, Ishihara $\mathrm{S}$, Sunami $\mathrm{E}$, Kitayama $\mathrm{J}$ and Watanabe T: Hereditary gastrointestinal cancer. Surg Today 46: 1115-1122, 2016.

2 Boland CR, Thibodeau SN, Hamilton SR, Sidransky D, Eshleman JR, Burt RW, Meltzer SJ, Rodriguez-Bigas MA, Fodde R, Ranzani GN and Srivastava S: A National Cancer Institute Workshop on Microsatellite Instability for cancer detection and familial predisposition: development of international criteria for the determination of microsatellite instability in colorectal cancer. Cancer Res 58: 5248-5257, 1998.

3 Jung WB, Kim CW, Yoon YS, Park IJ, Lim SB, Yu CS and Kim JC: Observational Study: Familial relevance and oncological significance of revised Bethesda guidelines in colorectal patients that have undergone curative resection. Medicine 95: e2723, 2016.

4 Rodriguez-Bigas MA, Boland CR, Hamilton SR, Henson DE, Jass JR, Khan PM, Lynch H, Perucho M, Smyrk T, Sobin L and Srivastava S: A National Cancer Institute Workshop on Hereditary Nonpolyposis Colorectal Cancer Syndrome: Meeting highlights and Bethesda guidelines. J Natl Cancer Inst 89: 17581762, 1997.

5 Umar A, Boland CR, Terdiman JP, Syngal S, de la Chapelle A, Ruschoff J, Fishel R, Lindor NM, Burgart LJ, Hamelin R, Hamilton SR, Hiatt RA, Jass J, Lindblom A, Lynch HT, Peltomaki P, Ramsey SD, Rodriguez-Bigas MA, Vasen HF, Hawk ET, Barrett JC, Freedman AN and Srivastava S: Revised Bethesda Guidelines for hereditary nonpolyposis colorectal cancer (Lynch syndrome) and microsatellite instability. J Natl Cancer Inst 96: 261-268, 2004.

6 Pinol V, Castells A, Andreu M, Castellvi-Bel S, Alenda C, Llor X, Xicola RM, Rodriguez-Moranta F, Paya A, Jover R and Bessa $\mathrm{X}$ : Accuracy of revised Bethesda guidelines, microsatellite instability, and immunohistochemistry for the identification of patients with hereditary nonpolyposis colorectal cancer. JAMA 293: 1986-1994, 2005. 
7 Umar A, Risinger JI, Hawk ET and Barrett JC: Testing guidelines for hereditary non-polyposis colorectal cancer. Nat Rev Cancer 4: 153-158, 2004.

8 Ishida H, Iwama T, Tomita N, Koizumi K, Akagi K, Ishiguro M, Watanabe $\mathrm{T}$ and Sugihara K: Diagnosis and management of hereditary colorectal cancer according to the JSCCR Guidelines 2012 for the Clinical Practice of Hereditary Colorectal Cancer. Nihon Rinsho 72: 143-149, 2014 (in Japanese).

9 Chou CL, Lin JK, Wang HS, Yang SH, Li AF and Chang SC: Microsatellite instability screening should be done for rightsided colon cancer patients less than 60 years of age. Int J Colorectal Dis 25: 47-52, 2010.

10 Hampel H, Frankel WL, Martin E, Arnold M, Khanduja K, Kuebler P, Nakagawa H, Sotamaa K, Prior TW, Westman J, Panescu J, Fix D, Lockman J, Comeras I and de la Chapelle A: Screening for the Lynch syndrome (hereditary nonpolyposis colorectal cancer). N Eng J Med 352: 1851-1860, 2005.

11 Jenkins MA, Hayashi S, O'Shea AM, Burgart LJ, Smyrk TC, Shimizu D, Waring PM, Ruszkiewicz AR, Pollett AF, Redston M, Barker MA, Baron JA, Casey GR, Dowty JG, Giles GG, Limburg P, Newcomb P, Young JP, Walsh MD, Thibodeau SN, Lindor NM, Lemarchand L, Gallinger S, Haile RW, Potter JD, Hopper JL and Jass JR: Pathology features in Bethesda guidelines predict colorectal cancer microsatellite instability: a population-based study. Gastroenterology 133: 48-56, 2007.

12 Julie C, Tresallet C, Brouquet A, Vallot C, Zimmermann U, Mitry E, Radvanyi F, Rouleau E, Lidereau R, Coulet F, Olschwang S, Frebourg T, Rougier P, Nordlinger B, LaurentPuig P, Penna C, Boileau C, Franc B, Muti C and HofmannRadvanyi H: Identification in daily practice of patients with Lynch syndrome (hereditary nonpolyposis colorectal cancer): revised Bethesda guidelines-based approach versus molecular screening. Am J Gastroenterol 103: 2825-2835, 2008.

13 Moreira L, Balaguer F, Lindor N, de la Chapelle A, Hampel H, Aaltonen LA, Hopper JL, Le Marchand L, Gallinger S, Newcomb PA, Haile R, Thibodeau SN, Gunawardena S, Jenkins MA, Buchanan DD, Potter JD, Baron JA, Ahnen DJ, Moreno V, Andreu M, Ponz de Leon M, Rustgi AK and Castells A: Identification of Lynch syndrome among patients with colorectal cancer. JAMA 308: 1555-1565, 2012.
14 Perez-Carbonell L, Ruiz-Ponte C, Guarinos C, Alenda C, Paya A, Brea A, Egoavil CM, Castillejo A, Barbera VM, Bessa X, Xicola RM, Rodriguez-Soler M, Sanchez-Fortun C, Acame N, Castellvi-Bel S, Pinol V, Balaguer F, Bujanda L, De-Castro ML, Llor X andreu M, Carracedo A, Soto JL, Castells A and Jover R: Comparison between universal molecular screening for Lynch syndrome and revised Bethesda guidelines in a large populationbased cohort of patients with colorectal cancer. Gut 61: 865-872, 2012.

15 Gospodarowicz MK, Brierley JD and Wittekind C: TNM Classification of Malignant Tumours. John Wiley \& Sons, 2017.

16 Rodriguez-Moranta F, Castells A, Andreu M, Pinol V, CastellviBel S, Alenda C, Llor X, Xicola RM, Jover R, Paya A, Bessa X, Balaguer F, Cubiella J, Arguello L, Morillas JD and Bujanda L: Clinical performance of original and revised Bethesda guidelines for the identification of $M S H 2 / M L H 1$ gene carriers in patients with newly diagnosed colorectal cancer: Proposal of a new and simpler set of recommendations. Am J Gastroenterol 101: 1104-1111, 2006.

17 Ishikubo T, Nishimura Y, Yamaguchi K, Khansuwan U, Arai Y, Kobayashi T, Ohkura Y, Hashiguchi Y, Tanaka Y and Akagi K: The clinical features of rectal cancers with high-frequency microsatellite instability (MSI-H) in Japanese males. Cancer Lett 216: 55-62, 2004.

18 Kadowaki S, Kakuta M, Takahashi S, Takahashi A, Arai Y, Nishimura Y, Yatsuoka T, Ooki A, Yamaguchi K, Matsuo K, Muro K and Akagi K: Prognostic value of KRAS and BRAF mutations in curatively resected colorectal cancer. World $\mathrm{J}$ Gastroenterol 21: 1275-1283, 2015.

19 Kumamoto K, Ishida H, Suzuki O, Tajima Y, Chika N, Kuwabara K, Ishibashi K, Saito K, Nagata K, Eguchi H, Tamaru $\mathrm{J}$ and Iwama T: Lower prevalence of Lynch syndrome in colorectal cancer patients in a Japanese hospital-based population. Surg Today 46: 713-720, 2016. 